\title{
KARAKTERISTIK LUAS PERMUKAAN KARBON AKTIF DARI AMPAS TEBU DENGAN AKTIVASI KIMIA
}

\author{
Mahmud Sudibandriyo*, Lydia \\ Departemen Teknik Kimia, Fakultas Teknik \\ Universitas Indonesia \\ Kampus UI, Depok 16424 \\ Email: msudib@che.ui.ac.id
}

\begin{abstract}
Abstrak
Adsorpsi merupakan salah satu proses yang banyak digunakan dalam industri baik dalam pemisahan maupun untuk penyimpanan gas. Pada proses adsorpsi ini, pemilihan adsorben merupakan hal yang sangat penting. Salah satu jenis adsorben yang sangat cocok untuk proses ini adalah karbon aktif. Penelusuran studi sebelumnya menunjukkan bahwa karbon aktif dengan luas permukaan yang cukup tinggi dapat dibuat dari ampas tebu dengan menggunakan aktivator $\mathrm{ZnCl}_{2}$. Penelitian ini bertujuan untuk menghasilkan karbon aktif dari ampas tebu dengan aktivasi kimia serta mengetahui pengaruh aktivator terhadap luas permukaan karbon aktif yang dihasilkan. Aktivator yang digunakan dalam penelitian ini adalah $\mathrm{KOH}$ dan $\mathrm{ZnCl}_{2}$ dengan rasio massa aktivator/massa karbon 1/1, 2/1, dan 3/1. Aktivasi dilakukan pada temperatur $700{ }^{\circ} \mathrm{C}$ selama 1 jam. Hasil penelitian menunjukkan bahwa luas permukaan tertinggi sebesar $938,2 \mathrm{~m}^{2} / \mathrm{g}$ diperoleh dengan aktivasi menggunakan $\mathrm{KOH}$ dengan rasio massa aktivator/massa arang $3 / 1$, sedangkan aktivasi dengan menggunakan $\mathrm{ZnCl}_{2}$ diperoleh luas permukaan tertinggi sebesar $632 \mathrm{~m}^{2} / \mathrm{g}$ dengan rasio massa aktivator/massa arang 2/1. Sebagai pembanding, pada penelitian ini juga dilakukan pembuatan karbon aktif dengan metode aktivasi fisika dan diperoleh luas permukaan karbon aktif sebesar $293 \mathrm{~m} 2 / \mathrm{g}$.
\end{abstract}

Kata kunci: Aktivasi kimia, ampas tebu, karbon aktif, $\mathrm{KOH}, \mathrm{ZnCl}_{2}$

\begin{abstract}
Adsorption is one the process with many applications in the industries such as in a separation or in gas storage. In this adsorption, adsorbent selection is the most important thing. One of the adsorbent most suitable for this process is activated carbon. Previous studies show that high surface area of activated carbon can be produced from sugarcane bagasse using activator $\mathrm{ZnCl}_{2}$. The research's goal is to produce activated carbon from sugarcane bagasse and determine the effects of activator on the surface area of activated carbon produced. Activators used in this research are $\mathrm{KOH}$ and $\mathrm{ZnCl}_{2}$ with the mass ratio of activator/carbon are 1/1,2/1 and 3/1. The results show that The highest surface area, 938,2 $\mathrm{m}^{2} / \mathrm{g}$, is obtained by activation using $\mathrm{KOH}$ with mass ratio of activator/carbon $3 / 1$, whereas the highest surface area by activation using $\mathrm{ZnCl}_{2}$ is $632 \mathrm{~m}^{2} / \mathrm{g}$ with mass ratio of activator/carbon 2/1. For comparison, preparation of activated carbon by physical activation is also done and the surface area is $293 \mathrm{~m}^{2} / \mathrm{g}$.
\end{abstract}

Keywords: Activated carbon, chemical activation, sugarcane bagasse, $\mathrm{KOH}, \mathrm{ZnCl}_{2}$

*korespondensi 


\section{Pendahuluan}

Adsorpsi merupakan salah satu dari proses pemisahan yang sudah lama dikenal dan banyak digunakan dalam industri. Beberapa tahun belakangan ini, proses adsorpsi banyak mendapat perhatian. Hal ini bukan hanya karena aplikasinya sebagai proses pemisahan yang banyak digunakan dalam industri kimia dan makanan, tetapi juga berhubungan dengan teknologi penyimpanan gas yang sedang dikembangkan, yaitu penyimpanan dalam keadaan teradsorpsi. Dalam teknologi ini, proses adsorpsi tidak digunakan untuk proses pemisahan, tetapi untuk menyimpan gas, seperti hidrogen, natural gas, dan karbon dioksida. Teknologi ini tentunya dapat membantu masalah penggunaan energi terbarukan yang masih terkendala dalam hal transportasi dan penyimpanan. Pentingnya proses adsorpsi ini menjadi pemicu dilakukannya banyak penelitian mengenai proses adsorpsimulai dari segi mekanisme sampai dengan pengembangan adsorben yang digunakan dalam proses adsorpsi.

Adsorben merupakan salah satu faktor yang penting dalam proses adsorpsi. Adsorben yang sering digunakan dalam proses adsorpsi ialah padatan berpori seperti zeolit, silika gel, dan karbon aktif. Dari beberapa jenis adsorben tersebut yang paling banyak digunakan ialah karbon aktif. Hal ini disebabkan karbon aktif memiliki luas permukaan yang lebih tinggi dari adsorbanadsorban yang lain sehingga dapat mengadsorpsi lebih banyak molekul. Konsumsi karbon aktif dunia meningkat setiap tahunnya. Menurut perkiraan sebuah riset, pada tahun 2014, konsumsi karbon aktif dunia mencapai 1,7 juta ton (Freedonia, 2010).

Karbon aktif dapat dibuat dari berbagai bahan baku asalkan mengandung karbon, misalnya tempurung kelapa, batu baea, kulit kacang, dan gambut (Devnarain dkk., 2010). Karbon aktif dengan luas permukaan terbesar yang pernah ditemukan (BET) adalah 3300 $\mathrm{m} 2 / \mathrm{g}$ dari bahan baku batu bara bituminous (Hsu dan Teng, 2000). Selain itu, limbah agrikultur juga dapat digunakan sebagai karbon aktif. Bahan limbah agrikultur yang cukup berpotensial untuk dikembangkan sebagai bahan baku karbon aktif adalah ampas penggilingan tebu, sekam padi, tongkol jagung dan sabut kelapa. Ampas tebu merupakan salah satu bahan yang cukup potensial dikembangkan di Indonesia karena ketersediaannya yang melimpah di Indonesia.

Dalam 10 tahun terakhir luas areal perkebunan tebu di Indonesia terus meningkat dengan pertumbuhan rata-rata sebesar 3,75\% per tahun dari hanya seluas 388.500 hektar pada 2000 meningkat menjadi 443.800 hektar tahun 2009 (BPS, 2010). Produksi gula tebu di Indonesia pada tahun 2009 mencapai sekitar 2,3 juta ton (BPS, 2010). Dari proses pembuatan gula tebu tersebut gula yang dihasilkan adalah sebesar $5 \%$, ampas tebu $90 \%$ dan sisanya berupa tetes. Dengan demikian jumlah ampas tebu yang dihasilkan dari proses ini bisa mencapai 37,8 juta ton per tahun. Oleh karena itu, sebagai alternatif, ampas tebu ini bisa dimanfaatkan untuk dibuat menjadi karbon aktif yang mempunyai nilai ekonomi lebih tinggi daripada hanya digunakan sebagai bahan bakar.

Penelitian ini bertujuan untuk menghasilkan karbon aktif dengan luas permukaan yang tinggi sehingga dapat digunakan untuk berbagai keperluan dalam proses adsorpsi. Penggunaan aktivator dalam proses aktivasinya diharapkan dapat menghasilkan karbon aktif dengan luas permukaan yang tinggi (Hsu dan Teng, 2000). Penelitian yang pernah dilakukan menggunakan aktivator $\mathrm{ZnCl}_{2}$ untuk pembuatan karbon aktif dari ampas tebu bisa menghasilkan karbon aktif dengan luas permukaan $864 \mathrm{~m}^{2} / \mathrm{g}$ (Kalderis dkk., 2008). Namun, dalam penelitian pembuatan karbon aktif dari batu bara diperoleh bahwa penggunaan aktivator $\mathrm{KOH}$ memberikan luas permukaan yang paling tinggi (Hsu dan Teng, 2000). Oleh karena itu, dalam penelitian ini digunakan aktivator $\mathrm{ZnCl}_{2}$ dan $\mathrm{KOH}$ untuk mengetahui pengaruh jenis aktivator yang digunakan terhadap luas permukaan karbon aktif yang dihasilkan. Sebagai pembanding, juga akan dilakukan pembuatan karbon aktif dari ampas tebu dengan pemanasan saja tanpa aktivator (aktivasi fisik).

\section{Metodologi}

Proses pembuatan karbon aktif dari ampas tebu ini menggunakan metode yang sudah dikembangkan sebelumnya untuk pembuatan karbon aktif dari batu bara dan tempurung kelapa. Ampas tebu yang digunakan berasal dari salah satu industri gula yang ada di Lampung. Proses awal pembuatan karbon aktif dari ampas tebu ialah 
proses karbonisasi dengan suhu $400{ }^{\circ} \mathrm{C}$, lalu hasilnya dicampur dengan aktivator dengan perbandingan tertentu. Setelah itu dilakukan proses pengaktifan di dalam reaktor, pengaktifan dilakukan pada suhu $700{ }^{\circ} \mathrm{C}$ dengan dialiri gas inert $\mathrm{N}_{2}$ selama 1 jam.

Setelah proses aktivasi, sampel (produk karbon aktif) didinginkan dengan tetap mengalirkan $\mathrm{N}_{2}$. Setelah didinginkan, sampel tersebut dicuci tiga kali dengan larutan $\mathrm{HCl}$ $5 \mathrm{~N}$ dan terakhir sampel dicuci dengan air distilasi beberapa kali untuk menghilangkan pengotor-pengotor yang masih tersisa. Setelah dicuci, sampel dikeringkan dalam oven. Sampel karbon aktif yang didapatkan kemudian disimpan di dalam desikator untuk menjaga karbon aktif tetap kering. Produk karbon aktif yang dihasilkan dianalisis luas permukaannya dengan metode BET menggunakan gas nitrogen pada alat Autosorb 6B produksi Quantachrome. Secara umum, tahapan-tahapan dari penelitian yang dilakukan dapat dilihat pada Gambar 1.

\section{Hasil dan Pembahasan}

\subsection{Hasil dan Proses Karbonisasi}

Proses karbonisasi dilakukan dengan tujuan untuk mendapatkan karbon dari ampas tebu yang digunakan sebagai bahan baku. Sebelum dilakukan karbonisasi, ampas tebu terlebih dahulu dihaluskan. Hal ini dilakukan dengan tujuan untuk pemerataan proses karbonisasi nantinya. Dari proses karbonisasi ampas tebu didapatkan perolehan rata-rata arang ampas tebu yang terbentuk ialah sebesar $24,07 \%$ dari berat awal ampas tebu yang digunakan dalam proses karbonisasi. Hal ini cukup masuk masuk akal mengingat kandungan karbon dalam ampas tebu umumnya memang dibawah $30 \%$. Tabel 1 menunjukkan hasil analisis proksimat ampas tebu.

Tabel 1. Hasil Analisis Proksimat Ampas Tebu

\begin{tabular}{lc}
\hline \multicolumn{1}{c}{ Parameter } & $\begin{array}{c}\text { Persentase } \\
\text { (\%) }\end{array}$ \\
\hline Kadar air & 6,1 \\
Kadar abu & 3,3 \\
Kadar material volatile & 65,9 \\
Kadar karbon & 24,7 \\
\hline
\end{tabular}

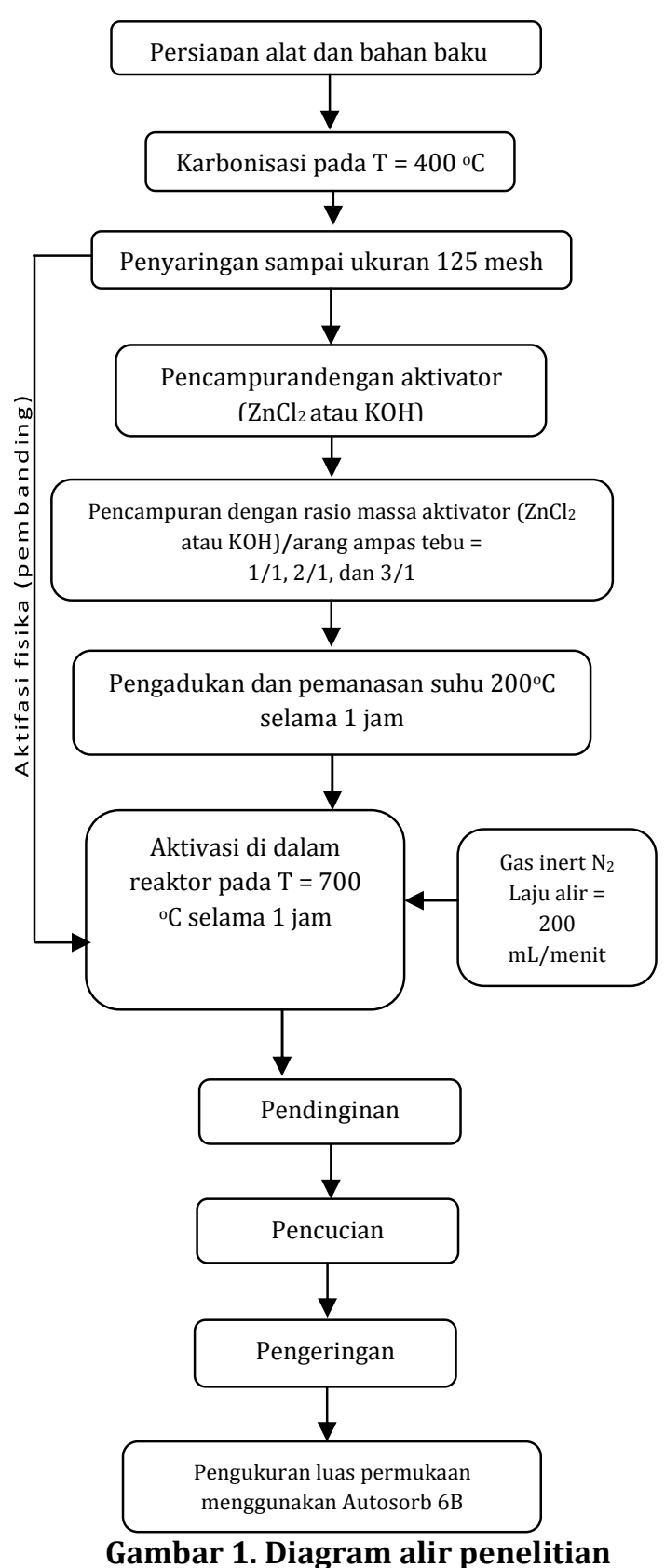

\subsection{Hasil Proses Aktivasi}

Setelah proses pencampuran dengan aktivator selesai dilakukan, maka proses selanjutnya adalah aktivasi. Slurry yang didapatkan dari proses pencampuran dengan bahan kimia dimasukan ke dalam reaktor untuk diaktivasi. Proses aktivasi pada karbon dilakukan dengan pemanasan pada suhu tinggi tanpa kehadiran oksigen. Hal ini karena kehadiran oksigen dapat membakar dan merusak struktur pori bahan dasar sehingga akan terjadi banyak hilangnya bahan dasar pada hasil akhir karbon aktif. Oleh karena itu untuk mencegah reaksi pembakaran dengan oksigen, maka dialirkan gas inert selama 
proses aktivasi, yaitu nitrogen. Dengan demikian, selama proses ini yang mengaktivasi karbon ialah aktivator yang telah dicampurkan sebelumnya. Proses aktivasi dilakukan pada suhu $700{ }^{\circ} \mathrm{C}$ selama 1 jam. Kondisi operasi ini dilakukan pada semua sampel, baik dengan aktivator $\mathrm{KOH}$ maupun dengan $\mathrm{ZnCl}_{2}$.

Massa karbon aktif yang merupakan hasil dari aktivasi berbeda jika dibandingkan dengan massa arang ampas tebu yang digunakan sebelum dicampur dengan aktivator seperti yang ditunjukkan pada Tabel 2. Massa arang ampas tebu yang digunakan untuk setiap perbandingan dibuat sama yaitu sekitar 20 gram. Dari tabel tersebut terlihat bahwa massa setelah proses aktivasi atau massa setelah keluar dari reaktor lebih besar dibandingkan dengan massa arang ampas tebu yang digunakan. Penambahan massa ini disebabkan karena masih adanya aktivator yang tersisa. Dalam proses aktivasi terjadi reaksi antara aktivator dengan arang atau karbon sehingga setelah keluar dari reaktor, ada massa yang hilang. Hal inilah yang menyebabkan massa yang keluar dari reaktor lebih sedikit dibandingkan dengan jumlah massa arang dan aktivator yang digunakan.

Tabel 2. Perbandingan Antara Massa Arang Ampas Tebu dan Massa Keluar Reaktor

\begin{tabular}{lllll}
\hline $\begin{array}{l}\text { Akti- } \\
\text { vator }\end{array}$ & $\begin{array}{l}\text { Massa } \\
\text { aktiva- } \\
\text { tor/ } \\
\text { arang }\end{array}$ & $\begin{array}{l}\text { Massa } \\
\text { arang + } \\
\text { aktiva- } \\
\text { tor, g }\end{array}$ & $\begin{array}{l}\text { Massa } \\
\text { keluar } \\
\text { reaktor, } \\
\text { g }\end{array}$ & $\begin{array}{l}\text { Jumlah } \\
\text { massa } \\
\text { yang } \\
\text { hilang } \\
\text { karena } \\
\text { reaksi, } \\
\text { g }\end{array}$ \\
\hline \multirow{2}{*}{$\mathrm{ZnCl}_{2}$} & $2: 1$ & 40,03 & 25,20 & 14,83 \\
& $3: 1$ & 60,03 & 30,95 & 29,08 \\
\hline & $1: 1$ & 40,09 & 27,87 & 12,22 \\
$\mathrm{KOH}$ & $2: 1$ & 60,09 & 36,62 & 23,47 \\
& $3: 1$ & 80,06 & 60,00 & 20,06 \\
\hline
\end{tabular}

Pada tabel di atas, jumlah massa yang hilang karena reaksi didapat dari perhitungan jumlah massa arang dan massa aktivator dikurangi dengan massa yang keluar reaktor. Semakin banyak massa yang hilang menandakan bahwa reaksi yang terjadi antara aktivator dengan karbon juga semakin banyak. Jika reaksi yang terjadi semakin banyak, maka pori-pori yang terbentuk juga semakin banyak. Pori-pori yang terbentuk inilah yang nantinya menentukan luas permukaan dari karbon aktif. Namun, reaksi ini juga diharapkan tidak menghabiskan karbon yang ada. Jika reaksi yang terjadi terlalu banyak, maka besar kemungkinan strukturpori yang terbentuk menjadi rusak yang dapat menghasilkan luas permukaan yang rendah pada karbon aktif.

Hasil perhitungan untuk aktivasi dengan aktivator $\mathrm{ZnCl}_{2}$ memperlihatkan bahwa semakin besar rasio massa aktivator/massa arang, maka massa karbon yang hilang karena reaksi semakin besar. Untuk kenaikan rasio massa aktivator/massa arang $1 / 1$ ke $2 / 1$, kenaikan massa yang hilang masih wajar, tetapi untuk rasio massa aktivator/massa arang 3/1, massa yang hilang karena reaksi sangat besar. Diduga terjadi reaksi yang berlebihan sehingga dapat merusak struktur pori pada karbon aktif seperti yang dijelaskan di atas. Berbeda halnya dengan aktivasi dengan menggunakan $\mathrm{KOH}$ sebagai aktivator. massa yang hilang tidak jauh berbeda untuk ketiga rasio massa aktivator/massa arang. Hal ini menandakan bahwa aktivator $\mathrm{KOH}$ yang digunakan tidak berlebihan sehingga tidak terjadi reaksi yang berlebihan pula.

\subsection{Hasil Karbon Aktif Setelah Pencucian}

Pada proses pencucian ini, pertamatama karbon aktif dicuci dengan $\mathrm{HCl} 5 \mathrm{~N}$ terlebih dahulu. Tujuan pencucian dengan $\mathrm{HCl}$ ini ialah menghilangkan pengotor hasil reaksi yang tersimpan dalam karbon aktif, menghilangkan sisa-sisa aktivator yang kemungkinan masih ada, serta mengurangi kadar abu. Pada saat $\mathrm{HCl}$ dicampurkan ke dalam karbon aktif hasil aktivasi timbul gelembung-gelembung. Hal ini diperkirakan merupakan gas hasil reaksi yang menempati pori-pori pada saat proses aktivasi sehingga pada saat proses pencucian, gas tersebut keluar dari pori-pori karbon aktif. Karbon aktif hasil aktivasi untuk semua sampel dicuci sebanyak tiga kali menggunakan $\mathrm{HCl}$. Saat proses pencucian ketiga dengan $\mathrm{HCl}$, gelembung-gelembung sudah tidak terbentuk lagi sehingga menandakan bahwa hasil reaksi maupun sisa aktivator sudah tidak ada lagi dalam karbon aktif.

Setelah selesai pencucian dengan $\mathrm{HCl}$, selanjutnya karbon aktif dicuci dengan aquadest untuk menghilangkan $\mathrm{HCl}$ yang masih terdapat dalam karbon aktif. Pencucian dengan aquadest ini dilakukan berkali-kali sampai $\mathrm{pH}$ netral dan selanjutnya dikeringkan 
di dalam oven. Gambar karbon aktif yang sudah dicuci dan dikeringkan dapat dilihat pada Gambar 2. Hasil karbon aktif yang didapatkan untuk aktivasi dengan $\mathrm{KOH}$ dan $\mathrm{ZnCl}_{2}$ tidak menunjukkan bentuk maupun warna yang berbeda.



Gambar 2. Hasil Akhir Karbon Aktif

Sesuai dengan tujuan dari proses pencucian ini, yaitu untuk menghilangkan pengotor hasil reaksi, sisa aktivator, serta kandungan abu, maka setelah proses pencucian ini terjadi pengurangan massa dari karbon aktif yang keluar dari reaktor (sebelum dicuci) dan massa karbon aktif yang telah dicuci dan dikeringkan seperti yang ditunjukkan pada Tabel 3.

Tabel 3. Hasil Proses Pencucian dan Pengeringan

\begin{tabular}{lllrl}
\hline $\begin{array}{l}\text { Akti- } \\
\text { vator }\end{array}$ & $\begin{array}{l}\text { Perban- } \\
\text { dingan } \\
\text { massa } \\
\text { aktivator } \\
\text { /arang }\end{array}$ & $\begin{array}{l}\text { Massa } \\
\text { yang } \\
\text { keluar } \\
\text { reaktor, } \\
\text { g }\end{array}$ & $\begin{array}{l}\text { Massa } \\
\text { karbon } \\
\text { aktif, g }\end{array}$ & $\begin{array}{l}\text { Pero- } \\
\text { lehan } \\
\text { karbon } \\
\text { aktif } \\
\text { (\%) }\end{array}$ \\
\hline \multirow{2}{*}{$\mathrm{ZnCl}_{2}$} & $1: 1$ & 25,20 & 11,69 & 46,40 \\
& $2: 1$ & 30,95 & 12,68 & 40,99 \\
& $3: 1$ & 27,00 & 7,09 & 26,26 \\
\hline \multirow{2}{*}{$\mathrm{KOH}$} & $1: 1$ & 27,87 & 11,84 & 42,48 \\
& $2: 1$ & 36,62 & 8,15 & 22,27 \\
& $3: 1$ & 60,00 & 9,31 & 15,51 \\
\hline
\end{tabular}

Dari hasil perhitungan di atas terlihat bahwa perolehan karbon aktif yang dihasilkan semakin rendah untuk perbandingan massa aktivator dan massa arang yang semakin besar. Semakin rendah perolehan karbon aktif yang dihasilkan menandakan bahwa hasil reaksi yang terdapat dalam karbon aktif yang keluar dari reaktor semakin banyak. Jadi jika persentase pertambahan massa pada perhitungan sebelumnya besar, maka perolehan karbon aktif pada tabel hasil perhitungan di atas seharusnya semakin kecil.
Untuk aktivator $\mathrm{KOH}$, persentase perolehan yang didapatkan sesuai dengan perhitungan sebelumnya, yaitu persentase penambahan massa setelah keluar reaktor semakin besar seiring dengan semakin besarnya rasio yang digunakan. Akan tetapi, untuk aktivator $\mathrm{ZnCl}_{2}$, menunjukkan perbedaan. Pada tabel hasil perhitungan di atas memperlihatkan bahwa semakin besar rasio antara massa aktivator dan massa arang, maka semakin rendah perolehan yang dihasilkan. Padahal pada perhitungan sebelumnya, pertambahan massa setelah keluar reaktor paling banyak pada perbandingan 2/1. Hal ini mungkin disebabkan karena adanya kesalahan relatif pada saat proses pencucian maupun pengeringan. Setelah selesai proses pencucian dan pengeringan, maka telah didapat karbon aktif yang murni. Proses selanjutnya yang dilakukan ialah karakterisasi luas permukaan dari karbon aktif yang dihasilkan.

\subsection{Analisis Luas Permukaan}

Luas permukaan karbon aktif sebagai adsorben merupakan salah satu parameter yang penting. Karbon aktif dapat dikatakan sebagai adsorben yang baik jika memiliki luas permukaan yang tinggi. Hal ini karena luas permukaan adsorben merupakan salah satu faktor utama yang mempengaruhi proses adsorpsi. Luas permukaan pada umumnya diukur dengan metode BET dengan gas nitrogen. Pada penelitian ini, untuk mengukur luas permukaan dari karbon aktif yang dihasilkan, digunakan alat Autosorb. Berikut hasil pengujian luas permukaan pada karbon aktif yang dihasilkan seperti yang ditunjukkan pada Tabel 4 .

Tabel 4. Hasil Pengujian Luas Permukaan

\begin{tabular}{cccc}
\hline $\begin{array}{c}\text { Jenis } \\
\text { Akti- } \\
\text { vasi }\end{array}$ & $\begin{array}{c}\text { Akti- } \\
\text { vator }\end{array}$ & $\begin{array}{c}\text { Perbandi- } \\
\text { ngan } \\
\text { massa } \\
\text { aktivator } \\
\text { / } \\
\text { arang }\end{array}$ & $\begin{array}{c}\text { Luas } \\
\text { Permukaan } \\
\text { BET }\left(\mathbf{m}^{2} / \mathbf{g}\right)\end{array}$ \\
\hline & & $1: 1$ & 613,4 \\
& $\mathrm{ZnCl}_{2}$ & $2: 1$ & 632,0 \\
Kimia & & $3: 1$ & 587,4 \\
\cline { 2 - 4 } & & $1: 1$ & 340,0 \\
& & $2: 1$ & 442,6 \\
\hline Fisika & & $3: 1$ & 938,2 \\
\hline
\end{tabular}


Dari hasil pengujian luas permukaan dapat dilihat bahwa jenis aktivator dan rasio massa aktivator/massa arang mempengaruhi luas permukaan karbon aktif yang dihasilkan. Luas permukaan karbon aktif tertinggi dicapai oleh karbon aktif dengan aktivasi menggunakan aktivator $\mathrm{KOH}$ dengan rasio massa aktivator/massa arang 3/1, sedangkan karbon aktif dengan metode aktivasi fisika memiliki luas permukaan terendah. hasil penelitian ini membuktikan bahwa penggunaan aktivasi kimia lebih baik dibandingkan dengan aktivasi fisika untuk pembuatan karbon aktif dari ampas tebu.

Luas permukaan dari karbon aktif yang diaktivasi menggunakan $\mathrm{ZnCl}_{2}$ sebenarnya juga menunjukkan hasil yang cukup baik. Untuk rasio massa aktivator/massa arang sebesar 1/1 dan 2/1 memberikan luas permukaan yang lebih tinggi dibandingkan dengan proses aktivasi dengan $\mathrm{KOH}$ dengan rasio yang sama. Hal ini diperkirakan pada rasio tersebut, jumlah $\mathrm{KOH}$ yang digunakan kurang sehingga reaksinya dengan karbon dari arang belum optimal. Namun, untuk rasio massa aktivator/massa arang sebesar 3/1, luas permukaan yang dihasilkan dengan aktivasi kimia menggunakan $\mathrm{KOH}$ jauh lebih besar dibandingkan dengan aktivasi menggunakan $\mathrm{ZnCl}_{2}$.

Menurut Hsu dan Teng (2000) dalam pembuatan karbon aktif dengan aktivasi kimia, aktivator yang lebih baik digunakan untuk material lignoselulosic, seperti ampas tebu, ialah aktivator yang bersifat asam, seperti $\mathrm{ZnCl}_{2}$ dan $\mathrm{H}_{3} \mathrm{PO}_{4}$, dibandingkan dengan aktivator yang bersifat basa, seperti $\mathrm{KOH}$. Hal ini karena material lignoselulosic memiliki kandungan oksigen yang tinggi dan aktivator yang bersifat asam tersebut bereaksi dengan gugus fungsi yang mengandung oksigen, sedangkan untuk aktivator $\mathrm{KOH}$ lebih dapat bereaksi dengan karbon sehingga bahan baku yang memiliki kandungan karbon yang tinggi lebih baik menggunakan aktivator $\mathrm{KOH}$. Alasan tersebut pula yang menjadi dasar pemilihan aktivator $\mathrm{ZnCl}_{2}$ digunakan dalam penelitian ini sehingga seharusnya karbon aktif yang dihasilkan dengan menggunakan aktivator $\mathrm{ZnCl}_{2}$ memiliki luas permukaan yang lebih tinggi dibandingkan dengan menggunakan $\mathrm{KOH}$ sebagai aktivator.

Menurut hasil pengujian luas permukaan yang didapat, ternyata aktivasi dengan menggunakan $\mathrm{KOH}$ sebagai aktivator menghasilkan luas permukaan yang paling tinggi dibandingkan dengan menggunakan $\mathrm{ZnCl2}$. Hal ini karena proses pembuatan karbon aktif yang sedikit berbeda dengan penelitian sebelumnya. Pada penelitian sebelumnya, material lignoselulosic atau bahan baku karbon aktif yang berasal dari limbah agrikultur tidak dikarbonisasi terlebih dahulu. Bahan baku tersebut langsung dicampurkan dengan aktivator sesuai dengan jenis dan rasio yang diinginkan dan kemudian diaktivasi (Kalderis dkk., 2008), sedangkan pada penelitian ini bahan baku ampas dikarbonisasi terlebih dahulu, kemudian dicampur dengan aktivator dan setelah itu diaktivasi. Jika bahan baku tidak dikarbonisasi terlebih dahulu, maka bahan baku yang digunakan memang lebih banyak mengandung oksigen, tetapi jika bahan baku dilakukan proses karbonisasi terlebih dahulu, maka sebagian besar senyawa-senyawa volatile hilang atau menguap sehingga bahan baku yang digunakan memiliki kandungan karbon yang cukup tinggi. Hal inilah yang menyebabkan terjadinya sedikit perbedaan pada hasil penelitian ini dengan penelitian sebelumnya.

Pada penelitian ini bahan baku dikarbonisasi terlebih dahulu sehingga bahan baku yang dicampur dengan aktivator memiliki kandungan karbon yang tinggi. Sesuai dengan penelitian sebelumnya, bahan baku yang memiliki kandungan karbon yang cukup tinggi akan menghasilkan luas permukaan yang lebih tinggi jika menggunakan $\mathrm{KOH}$ yang bersifat basa sebagai aktivator. Hal ini karena $\mathrm{KOH}$ sebagai aktivator dapat bereaksi dengan karbon pada bahan baku. Reaksi kimia yang terjadi ialah (Pujiyanto, 2010):

$6 \mathrm{KOH}+\mathrm{C} \leftrightarrow 4 \mathrm{~K}+\mathrm{CO} 2+2 \mathrm{H} 2 \mathrm{O}$
$6 \mathrm{KOH}+\mathrm{C} \leftrightarrow 2 \mathrm{~K}+3 \mathrm{H} 2+2 \mathrm{~K} 2 \mathrm{CO} 3$
$4 \mathrm{KOH}+2 \mathrm{CO} 2 \leftrightarrow 2 \mathrm{~K} 2 \mathrm{CO} 3+2 \mathrm{H} 2 \mathrm{O}$

Aktivator $\mathrm{KOH}$ bereaksi dengan karbon sehingga membentuk pori-pori, semakin banyaknya pori-pori yang terbentuk, maka luas permukaan yang dihasilkan juga semakin tinggi. Oleh karena itu, pada penelitian ini diperoleh karbon aktif dengan luas permukaan tertinggi dengan aktivasi kimia menggunakan $\mathrm{KOH}$. Tabel 4 di atas juga dapat ditunjukkan dalam gambar sebagaimana Gambar 3. 


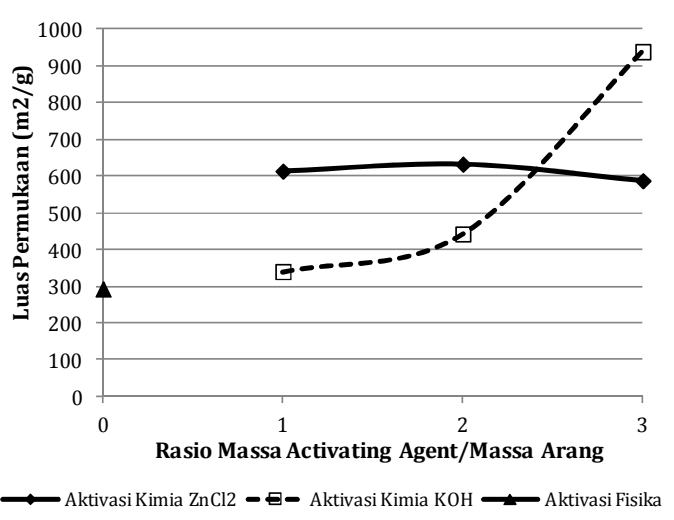

Gambar 3. Hubungan antara luas permukaan dan rasio massa aktivator /massa arang

Hasil luas permukaan tertinggi, yaitu sebesar 938,2 $\mathrm{m}^{2} / \mathrm{g}$ dicapai oleh karbon aktif dengan aktivasi kimia menggunakan $\mathrm{KOH}$. Untuk aktivasi kimia menggunakan $\mathrm{ZnCl}_{2}$, luas permukaan tertinggi yang diperoleh ialah 632 $\mathrm{m}^{2} / \mathrm{g}$. Luas permukaan karbon aktif yang dihasilkan dengan aktivasi fisika sangat rendah, yaitu $293 \mathrm{~m}^{2} / \mathrm{g}$. Suhu aktivasi yang digunakan pada penelitian ini cukup rendah jika digunakan untuk proses aktivasi fisika. Pada umumnya, untuk proses aktivasi fisika digunakan suhu di atas $900^{\circ} \mathrm{C}$. Penggunaan suhu aktivasi yang lebih rendah menjadi salah satu keunggulan proses aktivasi kimia dibandingkan dengan proses aktivasi fisika (Rodenas dkk., 2003).

Selain proses aktivasi dan jenis aktivator yang digunakan, rasio massa aktivator/massa arang juga mempengaruhi luas permukaan yang dihasilkan. Untuk aktivasi menggunakan $\mathrm{ZnCl}_{2}$, dari rasio $1 / 1 \mathrm{ke}$ rasio 2/1 terjadi kenaikan luas permukaan, tetapi untuk rasio 3/1 terjadi penurunan luas permukaan yang dihasilkan. Terlalu banyaknya aktivator yang digunakan juga dapat menyebabkan rusaknya pori-pori yang terbentuk karena terjadi reaksi yang berlebihan antara aktivator dengan karbon seperti yang dijelaskan pada pembahasan sebelumnya. Sesuai dengan penelitian sebelumnya, untuk pembuatan karbon aktif dengan aktivator $\mathrm{ZnCl}_{2}$, rasio optimum massa aktivator/massa arang yang digunakan ialah 2/1 (Hu dan Srinivasan, 2001). Penggunaan rasio yang lebih besar lagi dapat menyebabkan turunnya luas permukaan yang dihasilkan.
Pada aktivasi kimia menggunakan $\mathrm{KOH}$ sebagai aktivator,semakin besar rasio yang digunakan, maka semakin tinggi luas permukan yang dihasilkan. Namun, rasio massa aktivator/massa arang dalam penelitian ini belum diperoleh titik optimumnya sehingga belum diketahui rasio massa aktivator/massa arang maksimal yang dapat digunakan untuk menghasilkan luas permukaan tertinggi. Hasil penelitian Hsu dan Teng (2000) serta Pujiyanto (2010) dengan menggunakan bahan baku batubara dan aktivator $\mathrm{KOH}$ juga menunjukkan kecendurungan yang sama, dimana luas permukaan tertinggi diperoleh pada perbandingan mass $\mathrm{KOH} /$ massa batubara pada $4 / 1$.

Secara umum hasil penelitian ini cukup memadai mengingat bahwa karbon aktif yang ada di pasaran saat ini mempunyai luas permukaan antara 300-600 $\mathrm{m}^{2} / \mathrm{g}$ untuk karbon aktif yang dibuat secara tradisional, sementara karbon aktif impor mempunyai luas permukaan pada kisaran $800-1500 \mathrm{~m}^{2} / \mathrm{g}$.

\section{Kesimpulan}

Ampas tebu dapat digunakan sebagai bahan baku pembuatan karbon aktif. Metode aktivasi kimia menghasilkan luas permukaan yang lebih tinggi pada pembuatan karbon aktif dari ampas tebu jika dibandingkan dengan metode aktivasi fisika. Aktivator yang lebih baik digunakan untuk pembuatan karbon aktif dari ampas tebu dengan metode aktivasi kimia ialah $\mathrm{KOH}$. Perbandingan massa aktivator dengan arang ampas tebu yang digunakan berpengaruh terhadap luas permukaan karbon aktif yang dihasilkan. Untuk aktivasi menggunakan $\mathrm{ZnCl}$, rasio massa aktivator/massa arang yang menghasilkan luas permukaan tertinggi ialah 2/1 dengan luas permukaan sebesar 632 $\mathrm{m}^{2} / \mathrm{g}$. Untuk aktivasi menggunakan $\mathrm{KOH}$, rasio massa aktivator/massa arang yang menghasilkan luas permukaan tertinggi ialah 3/1 dengan luas permukaan sebesar 938,2 $\mathrm{m}^{2} / \mathrm{g}$.

\section{Daftar Pustaka}

Freedonia. World Activated Carbon [Online]. http://www.marketresearch.com/product/di splay.asp?productid=2717702 (Akses Maret 2011).

Devnarain, P. B.; Arnold, D. R.; Davis, S. B., Production of Activated Carbon from South 
African Sugarcane Bagasse, Proceedings of teh 76th Annual Congress of the South African Sugar Technologists' Association, Mount Edgecombe. 30 Juli-2 Agustus 2002, hal. 477489.

Hsu, L. Y.; Teng, H., Influence of different chemical reagents on the preparation of activated carbons from bituminous coal, Fuel Processing Technology, 2000, 64(1-3), 155166.

BPS, Produksi Perkebunan Besar menurut Jenis Tanaman, Indonesia , 1995-2009, Badan Pusat Statistik Republik Indonesia, http://www.bps.go.id/tab_sub/view.php?tabe $\mathrm{l}=1 \&$ daftar=1\&id_subyek=54\&notab=2 (Akses April 2011).

Kalderis, D.; Koutoulakis, D.; Paraskeva, P.; Diamadopoulos, E.; Otal, E.; Valle, J. O. D.;
Fernández-Pereira, C., Adsorption of polluting substances on activated carbons prepared from rice husk and sugarcane bagasse, Chemical Engineering Journal, 2008, 144(1), 42-50.

Pujiyanto, Pembuatan Karbon Aktif Super dari Batu Bara dan Tempurung Kelapa, Tesis, Departemen Teknik Kimia, Fakultas Teknik Universitas Indonesia, 2010.

Rodenas, M. A. L.; Amoros, D. C.; Solano, A. L., Understanding chemical reactions between carbons and $\mathrm{NaOH}$ and $\mathrm{KOH}$ : an insight into the chemical activation mechanism, Carbon, 2003, 41(2), 267-275.

$\mathrm{Hu}$, Z.; Srinivasan, M. P., Mesoporous highsurface-area activated carbon, Microporous and Mesoporous Materials, 2001, 43(3), 267275. 